\title{
Taxonomic Significance of Cellular Fatty Acid Composition in Some Coryneform Bacteria
}

\author{
KEN-ICHIRO SUZUKI ${ }^{* *}$ AND KAZUO KOMAGATA \\ Institute of Applied Microbiology, University of Tokyo, Bunkyo-ku, Tokyo 113, Japan
}

\begin{abstract}
A total of 76 strains of coryneform bacteria belonging to the genera Arthrobacter, Brevibacterium, Caseobacter, Cellulomonas, Corynebacterium, and Curtobacterium were divided into four groups on the basis of their cellular fatty acid compositions. Cells with saturated and monounsaturated straight-chain fatty acids were designated type I. Strains in this group had meso-diaminopimelic acid and arabinogalactan in their cell walls. In some strains, 10-methyl fatty acids were found. Type I was divided into six subtypes based on fatty acid composition. Type II cells contained iso-anteiso acids and were found in 43 strains of Arthrobacter, Brevibacterium, Cellulomonas, Curtobacterium, and coryneform bacteria with diaminobutyric acid-peptidoglycan. Small differences in fatty acid composition were found among the strains of this type, and the fatty acid compositions of type II strains varied remarkably depending on the media used. Type III strains were characterized by the presence of $\omega$-cyclohexyl fatty acids. In two strains of Curtobacterium pusillum, approximately $60 \%$ of the cellular fatty acid was $\omega$ cyclohexyl undecanoic acid. Type IV strains had highly complex patterns of iso, anteiso, normal, saturated, unsaturated, 10-methyl, and 2-hydroxy fatty acids. Five strains of Arthrobacter simplex, Arthrobacter tumescens, and "Brevibacterium lipolyticum" possessed this type of fatty acid composition.
\end{abstract}

Difficulties have been encountered in identifying and classifying coryneform bacteria belonging to the genera Arthrobacter, Brevibacterium, Caseobacter, Cellulomonas, Corynebacterium, Curtobacterium, and Microbacterium $(21,35$, 49). More recently, data on the deoxyribonucleic acid (DNA) base compositions $(2,8,38,48)$, DNA-DNA homologies $(9,13,39,40,42)$, peptidoglycan types in the cell walls $(12,22,23,36$, 47), phospholipid compositions $(4,5,25,29,31)$, isoprenoid quinones $(3-5,7,50)$, and acyl types in the cell walls $(44,45)$ of these organisms have been of great value in more precise characterizations of many coryneform bacteria $(21,49)$. Information regarding cellular fatty acid composition has been useful in bacterial taxonomy (16$19,30,34,46)$ and also has been applied to the taxonomy of some coryneform bacteria $(1,2,4$ $6,26,29,30,31$ ), but the number of coryneform strains heretofore examined has been rather limited. Recently, Suzuki et al. (43) found unusual fatty acids ( $\omega$-cyclohexyl fatty acids) in two strains of Curtobacterium pusillum.

In this study we examined the cellular fatty acid compositions of coryneform bacteria and the usefulness of this character for classification of bacteria. The effects of culture conditions on

† Present address: Japan Collection of Microorganisms, The Institute of Physical and Chemical Research, Wako-shi, Saitama 351, Japan. cellular fatty acid composition were investigated in order to determine the reliability of this characteristic for taxonomic purposes among coryneform bacteria.

\section{MATERIALS AND METHODS}

Abbreviations. The following culture collection abbreviations are used below: AJ, Central Research Laboratories, Ajinomoto Co., Inc., Kawasaki, Japan; ATCC, American Type Culture Collection, Rockville, Md.; CCEB, Culture Collection of Entomogenous Bacteria, Department of Insect Pathology, Institute of Entomology, Prague, Czechoslovakia; CCM, Czechoslovak Collection of Microorganisms, J. E. Purkyne University, Brno, Czechoslovakia; IAM, Institute of Applied Microbiology, University of Tokyo, Tokyo, Japan; IFM, Institute of Food Microbiology, Chiba University, Chiba, Japan; IFO, Institute for Fermentation, Osaka, Japan; LMD, Laboratorium voor Microbiologie der Landbouwhogeschool, Wageningen, The Netherlands; NCIB, National Collection of Industrial Bacteria, Torry Research Station, Aberdeen, Scotland; NCPPB, National Collection of Plant Pathogenic Bacteria, Harpenden, England; NRRL, Northern Utilization Research and Development Division, U.S. Department of Agriculture, Peoria, Ill.

The following abbreviations are used for fatty acids: $\mathrm{n}$, normal acid; $\mathrm{i}$, iso acid; $\mathrm{a}$, anteiso acid; $10-\mathrm{Me}, 10$ methyl acid; ch, $\omega$-cyclohexyl fatty acid; $2-\mathrm{OH}$ and $\mathrm{h}$, 2-hydroxy fatty acid. For example, i-16, a-15, 10-Me19 , ch-17, and 18:1 are abbreviations for 14-methyl pentadecanoic acid, 12-methyl tetradecanoic acid, 10methyl octadecanoic acid, $\omega$-cyclohexyl undecanoic acid, and $n$-octadecenoic acid, respectively. Unsatu- 
rated fatty acids are straight-chain acids unless specified otherwise.

DNA, Deoxyribonucleic acid.

Bacterial strains. A total of 76 strains of coryneform bacteria belonging to the genera Arthrobacter (15 strains), Brevibacterium (12 strains), Caseobacter (1 strain), Cellulomonas (2 strains), Corynebacterium (27 strains), and Curtobacterium (19 strains) were used in this study. In the list below, the strains are arranged in groups according to the chemotaxonomic concepts proposed by Yamada and Komagata (49) and Keddie (21). (Names which do not appear on the Approved Lists of Bacterial Names [37] are enclosed in quotation marks.)

(i) Group 1: Corynebacterium. Group 1 contained "Arthrobacter albidus" CNF 092 (= NCIB $10266=$ ATCC 15243) (23, 36), "Brevibacterium alkanolyticum" CNF 157 (= IFO $12323=$ ATCC 21033) (36), Brevibacterium ammoniagenes $\mathrm{CNF} 096^{\mathrm{T}}$ (type strain) $\left(=\mathrm{AJ} 1443^{\mathrm{T}}=\operatorname{ATCC} 6871^{\mathrm{T}}=\operatorname{NCIB~8143^{\mathrm {T}}}\right)(23,49)$, Brevibacterium ammoniagenes CNF 012 (= AJ 1444 $=\operatorname{ATCC} 6872)(36,49)$, Brevibacterium divaricatum CNF $013^{\mathrm{T}}\left(=\right.$ AJ $1498^{\mathrm{T}}=$ NRRL B-2312 ${ }^{\mathrm{T}}=$ ATCC $\left.14020^{\mathrm{T}}\right)(23,36,49)$, "Brevibacterium flavum" CNF 014 (= AJ $1510=$ ATCC 14067) $(23,36,49)$, "Brevibacterium thiogenitalis" CNF 160 (= IFO $12115=$ ATCC 19240) (30), Corynebacterium diphtheriae CNF 017 (= AJ 1414 = ATCC 11913) (49), Corynebacterium equi CNF 002 $2^{\mathrm{T}}\left(=\right.$ AJ $1402^{\mathrm{T}}=$ ATCC $6939^{\mathrm{T}}=$ IAM $\left.12426^{\mathrm{T}}\right)(36,49)$, Corynebacterium equi CNF $003(=$ AJ $1403=$ ATCC 10146 = IAM 12444) (49), Corynebacterium equi CNF 004 (= AJ $1372=$ IAM 12445) (49), Corynebacterium equi CNF 005 (= AJ $1376=$ IAM 12446) (49), Corynebacterium equi CNF 001 (= AJ 1378 = IAM 12443) (49), Corynebacterium fascians CNF 006 ${ }^{\mathrm{T}}\left(=\mathrm{AJ} 1398^{\mathrm{T}}=\right.$ ATCC $12974^{\mathrm{T}}=$ IAM $\left.12427^{\mathrm{T}}\right)(36,49)$, Corynebacterium flavescens $\mathrm{CNF}$

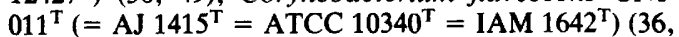
49), Corynebacterium glutamicum CNF $016^{\mathrm{T}}$ (= AJ $1502^{\mathrm{T}}=$ ATCC $13032^{\mathrm{T}}=$ IAM 12435 $5^{\mathrm{T}}$ (49), Corynebacterium hoagii CNF $007^{\mathrm{T}}\left(=\mathrm{AJ} 1408^{\mathrm{T}}=\mathrm{ATCC}\right.$ $7005^{\mathrm{T}}=$ IAM $12428^{\mathrm{T}}$ ) (49), "Corynebacterium hofmannii"' CNF 128 (= R. M. Keddie R76) (23), Corynebacterium lilium CNF $015^{\mathrm{T}}\left(=\mathrm{AJ} 1517^{\mathrm{T}}=\right.$ NRRL B$2243^{T}=$ ATCC $15990^{T}$ ) (49), Corynebacterium renale CNF 009 (= AJ $1411=$ ATCC $10848=$ IAM 12430) (49), Corynebacterium vitarumen $\mathrm{CNF} 008^{\mathrm{T}}(=\mathrm{AJ}$ $1525^{\mathrm{T}}=$ ATCC $\left.10234^{\mathrm{T}}=\operatorname{IAM} 12429^{\mathrm{T}}\right)(36,49)$, Corynebacterium xerosis CNF 010 (= AJ $1396=$ ATCC 7711 = IAM 12431) $(36,49)$, Corynebacterium xerosis CNF 093 (= NCIB $9956=$ CCM $1729=$ IAM 12583), and Corynebacterium xerosis CNF 094 (= NCIB $10087=$ NCTC $9755=$ IAM 12584).

(ii) Group 2: Brevibacterium. Group 2 included Brevibacterium linens CNF $019^{\mathrm{T}}\left(=\right.$ AJ $1521^{\mathrm{T}}=$ ATCC $9172^{\mathrm{T}}=$ IAM $\left.12437^{\mathrm{T}}\right)(36,49)$, and Brevibacterium linens CNF $018(=$ AJ $1520=$ ATCC $8377=$ IAM 12436) $(36,49)$.

(iii) Group 3: Arthrobacter. Group 3 contained Arthrobacter atrocyaneus CNF $064^{\mathrm{T}}$ (= IAM $12330^{\mathrm{T}}=$ CCM $1645^{\mathrm{T}}=$ ATCC $13752^{\mathrm{T}}$ ) (36), Arthrobacter aurescens CNF $103^{\mathrm{T}}\left(=\right.$ IAM $12340^{\mathrm{T}}=\mathrm{CCM} 1649^{\mathrm{T}}=$ ATCC $\left.13344^{\mathrm{T}}\right)(36,49)$, Arthrobacter citreus CNF $021^{\mathrm{T}}\left(=\mathrm{AJ} 1423^{\mathrm{T}}=\right.$ ATCC $\left.11624^{\mathrm{T}}=\operatorname{IAM~12341}{ }^{\mathrm{T}}\right)(36$, 49), Arthrobacter globiformis CNF $022^{\mathrm{T}}$ (= AJ $1422=$ ATCC $8010^{\mathrm{T}}=$ IAM $\left.12438^{\mathrm{T}}\right)(36,49)$, Arthrobacter nicotianae CNF $104^{\mathrm{T}}\left(=\right.$ IAM $12342^{\mathrm{T}}=\mathrm{CCM} 1648^{\mathrm{T}}=$
ATCC $\left.15236^{\mathrm{T}}\right)(36,49)$, Arthrobacter ramosus CNF $102^{\mathrm{T}}\left(=\right.$ AAM $12344^{\mathrm{T}}=$ CCM $1646^{\mathrm{T}}=$ ATCC $\left.13727^{\mathrm{T}}\right)$ (36, 49), Arthrobacter tumescens CNF 065 (= IAM $1447=$ AJ 1549), (15, 49), Arthrobacter tumescens CNF 066 (= IAM $1458=$ AJ 1460) $(15,49)$, Arthrobacter ureafaciens CNF 023 ${ }^{\mathrm{T}}\left(=\mathrm{AJ} 1421^{\mathrm{T}}=\mathrm{ATCC}\right.$ $7562^{\mathrm{T}}=$ IAM $\left.1658^{\mathrm{T}}\right)(36,49)$, Arthrobacter sp. strain CNF 108 (= AJ 1488 = ATCC $19098=$ = "Brevibacterium sulfureum" 8-3) $(15,36,49)$, and "Brevibacterium helvolum" CNF $020(=$ AJ $1445=$ ATCC $11822=$ IAM 1637) $(35,49)$.

(iv) Group 4: Cellulomonas. Group 4 included Cellulomonas biazotea CNF $024^{\mathrm{T}}\left(=\mathrm{AJ} 1569^{\mathrm{T}}=\mathrm{ATCC}\right.$ $\left.486^{\mathrm{T}}=\operatorname{IAM} 12106^{\mathrm{T}}\right)(12,36,49)$ and Cellulomonas fimi CNF $025^{\mathrm{T}}\left(=\right.$ AJ $1571^{\mathrm{T}}=$ ATCC $484^{\mathrm{T}}=$ IAM $\left.12107^{\mathrm{T}}\right)(12,36,49)$.

(v) Group 5: Curtobacterium. Group 5 contained Arthrobacter terregens CNF $111^{\mathrm{T}}$ (= NCIB $8909^{\mathrm{T}}$ ATCC $13345^{\mathrm{T}}$ ) (36), "Corynebacterium barkeri"' CNF 095 (= NCIB 9658 = ATCC 15954 = IAM 12585) (36), Curtobacterium albidum CNF $028^{\mathrm{T}}\left(=\mathrm{AJ} 1472^{\mathrm{T}}=\right.$ IAM $1631^{\mathrm{T}}=$ ATCC $\left.15831^{\mathrm{T}}\right)(24,36,49)$, Curtobacterium citreum CNF 026 ${ }^{\mathrm{T}}\left(=\right.$ AJ $1469^{\mathrm{T}}=$ IAM $1614^{\mathrm{T}}=$ ATCC $\left.15828^{\mathrm{T}}\right)(24,36,49)$, Curtobacterium citreum CNF 061 (= AJ $1471=$ IAM 12545) $(24,36,49)$, Corynebacterium flaccumfaciens CNF 029 (= AJ 1400 $=$ ATCC 6887) $(36,49)$, "Curtobacterium insectiphilium" CNF 059 (= AJ $1477=$ IFM AM-23 = IAM 12546) (49), Corynebacterium poinsettiae CNF 027 (= AJ 1999 = CCM 1587 = ATCC 9682) $(36,49)$, Curtobacterium pusillum CNF $106^{\mathrm{T}}$ (= IAM $1479^{\mathrm{T}}=\mathrm{ATCC}$ $\left.19096^{\mathrm{T}}\right)(15,36,43,49)$, Curtobacterium pusillum $\mathrm{CNF}$ 107 (= IAM 1489 = ATCC 19097) $(15,36,43,49)$, Curtobacterium saperdae CNF $058^{\mathrm{T}}\left(=\mathrm{AJ} 3126^{\mathrm{T}}=\right.$ CCEB $366^{\mathrm{T}}=$ ATCC $19272^{\mathrm{T}}$ ) (36), Curtobacterium testaceum CNF 032 ${ }^{\mathrm{T}}\left(=\right.$ AJ $1466^{\mathrm{T}}=$ IAM $1561^{\mathrm{T}}=$ ATCC $15829^{\mathrm{T}}$ ) (24) (Yamada and Komagata [49] miscited Curtobacterium testaceum AJ 1464 [ = Rp-1] as the type strain; in the original paper Komagata and Iizuka [24] designated strain Rp-3 [= AJ 1466 = IAM 1561] as the type strain of this species), Curtobacterium testaceum CNF 030 (= AJ 1464 = IAM 1537) (24, 49), Curtobacterium testaceum CNF 031 (= AJ $1465=$ IAM 1549) (24), Curtobacterium testaceum CNF 033 (= AJ 1467 = IAM 1572) (24), Curtobacterium testaceum CNF 034 (= AJ 1468 = IAM 1583) (24), Curtobacterium sp. strain CNF 116 (= Nakayama et al. 1142), Curtobacterium sp. strain CNF 162 (= IAM 1478 [Brevibacterium helvolum strain 129] = NCIB 10353) $(15,49)$, Curtobacterium sp. strain CNF 163 (= IAM 1434 [Brevibacterium helvolum strain 9-6] = ATCC 21342) $(15,49)$, Curtobacterium sp. strain CNF 164 (= IAM 1391 [Brevibacterium helvolum strain 123]) (15, 49), and Curtobacterium sp. strain CNF 165 (= IAM 1498 [Brevibacterium helvolum strain 9-8] = NCIB 10352) $(15,49)$.

(vi) Group 6: coryneform bacteria with LL-diaminopimelic acid in their cell walls. Group 6 included Arthrobacter simplex CNF 035 $5^{\mathrm{T}}\left(=\right.$ AJ $1420^{\mathrm{T}}=$ ATCC $6946^{\mathrm{T}}$ $=$ IAM $\left.1660^{\mathrm{T}}\right)(23,36,49)$, Arthrobacter simplex CNF $091(=$ NCIB $9770=$ IAM 12581) $(23,36)$, Arthrobacter tumescens CNF 067 ${ }^{\mathrm{T}}\left(=\mathrm{IAM} 12345^{\mathrm{T}}=\mathrm{CCM}\right.$ $1655^{\mathrm{T}}=$ ATCC $6947^{\mathrm{T}}(23,36,49)$, "Brevibacterium lipolyticum" CNF 036 (= AJ $1450=$ IAM 1398) (49), and "Brevibacterium lipolyticum" CNF 037 (= AJ 1451 = IAM 1413) (49).

(vii) Group 7: coryneform bacteria with diaminobu- 
TABLE 1. Cellular fatty acid compositions of coryneform bacteria: type I (normal-unsaturated type)

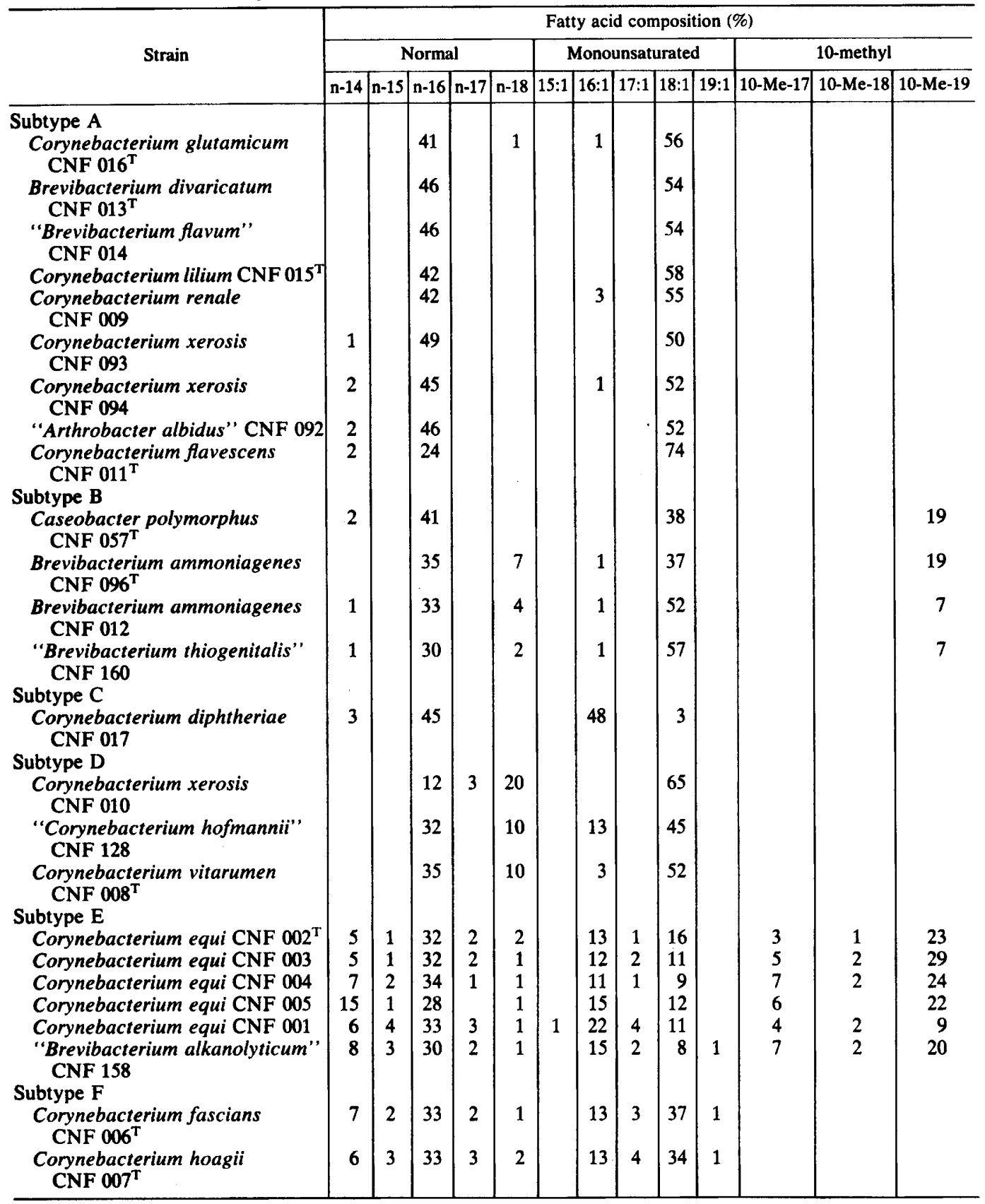

tyric acid in their cell walls. Group 7 contained " Corynebacterium aquaticum" CNF 038 ( = AJ 1413 = ATCC 14665 = IAM 12441) $(23,36,49)$, Corynebacterium insidiosum CNF 101 (= AJ $1409=$ ATCC $10253=$ NCPPB 852) $(36,49)$, Corynebacterium michiganense CNF 039 (= AJ $1390=$ ATCC 492) $(36,49)$, Corynebacterium michiganense CNF 097 (= AJ $1391=$ ATCC 4450) $(36,49)$, Corynebacterium michiganense CNF 098 (= AJ $1392=$ ATCC 7429) $(36,49)$, Coryne- bacterium michiganense CNF 099 (= AJ $1393=$ ATCC $7430=$ NCPPB 861) (49), Corynebacterium michiganense CNF 100 (= AJ $1394=$ ATCC 10202) (36, 49), Corynebacterium sp. strain CNF 133 (= R. M. Keddie A4) (23), and Corynebacterium sp. strain CNF 134 (= R. M. Keddie A112 [Flavobacterium dehydrogenans]) (23).

(viii) Genus Caseobacter. One member of the genus Caseobacter was studied, Caseobacter polymorphus 


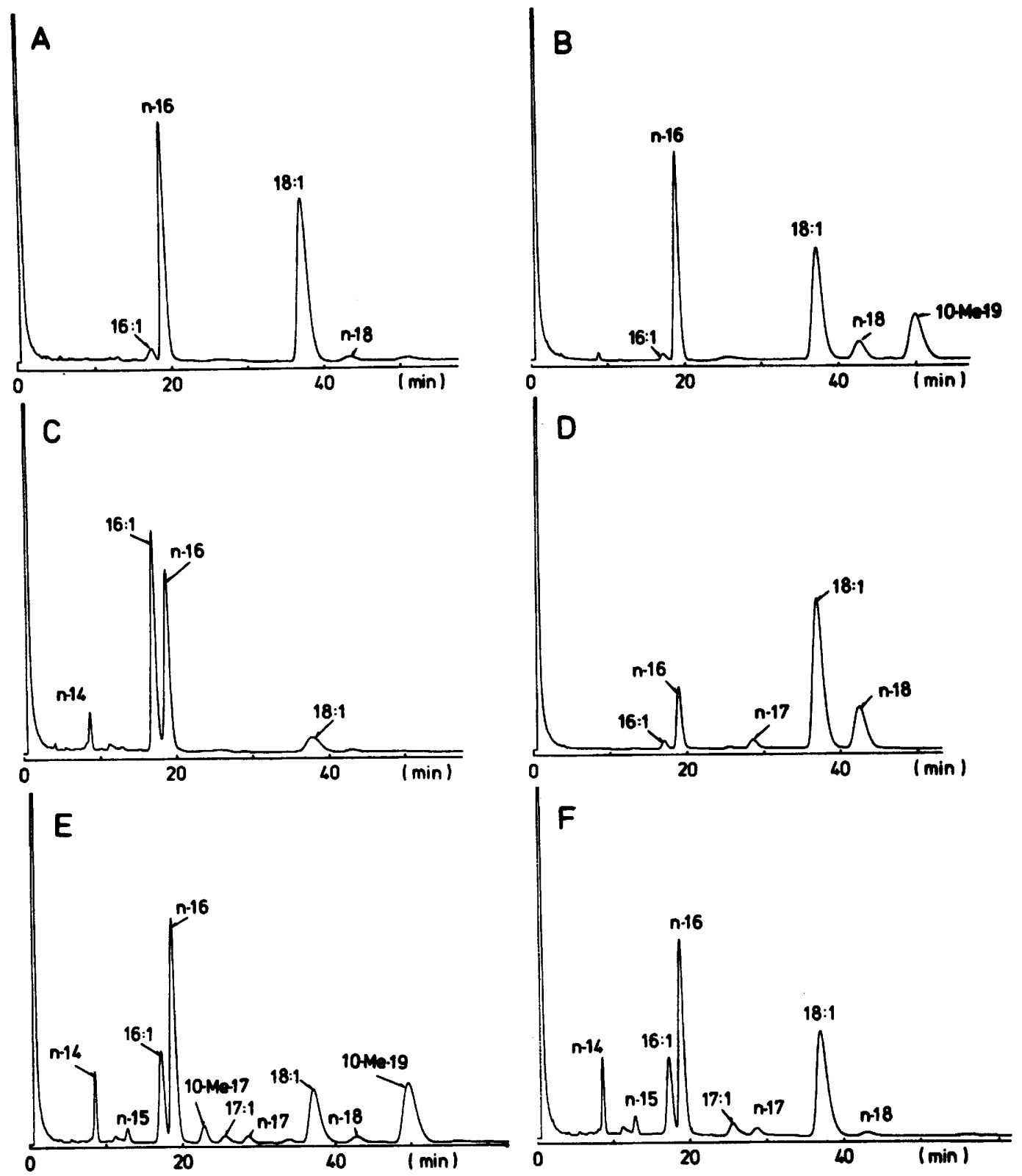

FIG. 1. Gas-liquid chromatograms of representatives of the six subtypes of cellular fatty acid type I (normalunsaturated type). (A) Subtype A (Corynebacterium glutamicum CNF 016 ${ }^{\mathrm{T}}$ ). (B) Subtype B (Brevibacterium ammoniagenes CNF $096^{\mathrm{T}}$ ). (C) Subtype C (Corynebacterium diphtheriae CNF 017). (D) Subtype D (Corynebacterium xerosis CNF 010). (E) Subtype E (Corynebacterium equi CNF 002 ${ }^{\mathrm{T}}$ ). (F) Subtype F (Corynebacterium fascians CNF $006^{\mathrm{T}}$ ). A 2-m OV-1 column was used. For abbreviations of fatty acids, see text.

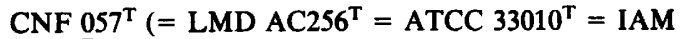
$\left.12549^{\mathrm{T}}\right)(10)$.

(xi) Unclassified strain. We included one unclassified strain in this study, Brevibacterium imperiale CNF $105^{\mathrm{T}}\left(=\right.$ IAM $1654^{\mathrm{T}}=\operatorname{ATCC} 8365^{\mathrm{T}}(36,49)$.

Culture media and cultivation of bacteria. Medium $F$ was used throughout this study unless otherwise stated. Medium F contains 1\% Bacto-Peptone (Difco
Laboratories, Detroit, Mich.), $0.5 \%$ yeast extract, $0.5 \%$ Casamino Acids (Difco), $0.5 \%$ malt extract, and $0.05 \% \mathrm{KH}_{2} \mathrm{PO}_{4}$ (pH 7.2). Bacteria were grown in 500 ml conical flasks containing $200 \mathrm{ml}$ of medium at $30^{\circ} \mathrm{C}$ for $24 \mathrm{~h}$ on a rotary shaker unless otherwise specified. Corynebacterium diphtheriae CNF 017 was grown at $37^{\circ} \mathrm{C}$.

Preparation of cellular fatty acid methyl esters. Cellu- 
TABLE 2. Cellular fatty acid compositions of coryneform bacteria: type II (iso-anteiso type)

\begin{tabular}{|c|c|c|c|c|c|c|c|c|c|c|c|}
\hline \multirow{3}{*}{ Strain } & \multicolumn{11}{|c|}{ Fatty acid composition (\%) } \\
\hline & \multicolumn{2}{|c|}{ Anteiso } & \multicolumn{4}{|c|}{ Iso } & \multicolumn{5}{|c|}{ Normal } \\
\hline & $a-15$ & a-17 & $\mathrm{i}-14$ & $\mathrm{i}-15$ & $\mathrm{i}-16$ & $\mathrm{i}-17$ & $\mathrm{n}-14$ & n-15 & $\mathrm{n}-16$ & $\mathrm{n}-17$ & $\mathrm{n}-18$ \\
\hline \multicolumn{12}{|l|}{ Group 2: Brevibacterium } \\
\hline Brevibacterium linens CNF $019^{\mathrm{T}}$ & 48 & 42 & 11 & 4 & 3 & 3 & & & & & \\
\hline Brevibacterium linens CNF 018 & 55 & 32 & 1 & 7 & 2 & 2 & & & & & \\
\hline \multicolumn{12}{|l|}{ Group 3: Arthrobacter } \\
\hline Arthrobacter globiformis CNF $022^{\mathrm{T}}$ & 53 & 18 & 1 & 4 & 5 & 1 & 3 & 1 & 12 & & 2 \\
\hline Arthrobacter citreus $\mathrm{CNF} 021^{\mathrm{T}}$ & 57 & 8 & 2 & 7 & 7 & 1 & 2 & 1 & 11 & & \\
\hline Arthrobacter nicotianae CNF $104^{\mathrm{T}}$ & 54 & 11 & 2 & 6 & 10 & 1 & 3 & & 12 & & \\
\hline Arthrobacter tumescens CNF 065 & 44 & 16 & & 17 & 4 & & 1 & 1 & 8 & 5 & 1 \\
\hline Arthrobacter tumescens CNF 066 & 39 & 17 & & 13 & 4 & 4 & 1 & & 11 & & 5 \\
\hline Arthrobacter atrocyaneus CNF $064^{\mathrm{T}}$ & 36 & 31 & 1 & 13 & 7 & 6 & & & 2 & & 1 \\
\hline "Brevibacterium helvolum' CNF 020 & 53 & 18 & 1 & 17 & 3 & 3 & 1 & & 4 & & \\
\hline Arthrobacter ureafaciens CNF $023^{\mathrm{T}}$ & 58 & 28 & 1 & 5 & 6 & 2 & & & 1 & & 1 \\
\hline Arthrobacter ramosus CNF $102^{\mathrm{T}}$ & 69 & 26 & & 1 & 2 & & & & 1 & & \\
\hline Arthrobacter aurescens CNF $103^{\mathrm{T}}$ & 66 & 26 & & 2 & 4 & 1 & & & 1 & & \\
\hline Arthrobacter sp. strain CNF 108 & 69 & 10 & 1 & 6 & 5 & 1 & 2 & & 6 & & \\
\hline \multicolumn{12}{|l|}{ Group 4: Cellulomonas } \\
\hline Cellulomonas fimi CNF $025^{\mathrm{T}}$ & 46 & 12 & 2 & 8 & 4 & 1 & 5 & 2 & 10 & 4 & 6 \\
\hline Cellulomonas biazotea CNF $024^{\mathrm{T}}$ & 48 & 13 & 3 & 5 & 4 & 1 & 3 & 5 & 8 & 5 & 4 \\
\hline \multicolumn{12}{|l|}{ Group 5: Curtobacterium } \\
\hline Curtobacterium citreum CNF $026^{\mathrm{T}}$ & 36 & 36 & 1 & 2 & 11 & 1 & 1 & 1 & 8 & 1 & 2 \\
\hline Curtobacterium citreum CNF 061 & 40 & 39 & 1 & 4 & 10 & 1 & & 1 & 3 & 1 & 2 \\
\hline "Curtobacterium poinsettiae" CNF 027 & 32 & 45 & & 2 & 13 & 1 & & & 3 & & 2 \\
\hline Curtobacterium albidum CNF $028^{\mathrm{T}}$ & 33 & 46 & 1 & 2 & 10 & 3 & & 1 & 3 & & 2 \\
\hline "Curtobacterium flaccumfaciens"' CNF 029 & 52 & 33 & 1 & 3 & 5 & 1 & & & 2 & & 2 \\
\hline "Curtobacterium insectiphilium" CNF 059 & 42 & 34 & & 1 & 14 & 2 & & & 4 & & 3 \\
\hline "Corynebacterium barkeri" CNF 095 & 34 & 46 & 1 & & 16 & & & & 3 & & \\
\hline Curtobacterium testaceum $\mathrm{CNF} 032^{\mathrm{T}}$ & 28 & 37 & & 4 & 19 & 2 & & 2 & 3 & 1 & 2 \\
\hline Curtobacterium testaceum CNF 030 & 23 & 46 & & 2 & 16 & 4 & & & 5 & & 2 \\
\hline Curtobacterium testaceum CNF 031 & 28 & 44 & 1 & 1 & 17 & 2 & 1 & 1 & 4 & 1 & 1 \\
\hline Curtobacterium testaceum CNF 033 & 28 & 37 & & 4 & 19 & 2 & & 2 & 3 & 1 & 2 \\
\hline Curtobacterium testaceum CNF 034 & 24 & 48 & & 1 & 16 & 2 & & 1 & 4 & 1 & 3 \\
\hline Arthrobacter terregens CNF $111^{\mathrm{T}}$ & 26 & 55 & & 1 & 15 & & & & 1 & 1 & \\
\hline Curtobacterium saperdae CNF $058^{\mathrm{T}}$ & 43 & 26 & & 2 & 16 & 2 & & & 7 & & 2 \\
\hline Curtobacterium sp. strain CNF 116 & 51 & 20 & & 3 & 13 & 8 & & & 1 & 1 & 2 \\
\hline Curtobacterium sp. strain CNF 162 & 43 & 35 & & & 19 & & & & 2 & & \\
\hline Curtobacterium sp. strain CNF 163 & 40 & 38 & & 1 & 17 & 1 & & & 3 & & \\
\hline Curtobacterium sp. strain CNF 164 & 43 & 37 & & 1 & 14 & 1 & & & 2 & & \\
\hline \multicolumn{12}{|l|}{$\begin{array}{l}\text { Group 7: coryneform bacteria with } \\
\text { diaminobutyric acid }\end{array}$} \\
\hline Corynebacterium michiganense CNF 039 & 56 & 33 & & & 9 & & & & 2 & & \\
\hline Corynebacterium michiganense CNF 097 & 52 & 34 & & & 9 & & & 1 & 2 & & \\
\hline Corynebacterium michiganense CNF 098 & 48 & 36 & & & 8 & & & 3 & 3 & & \\
\hline Corynebacterium michiganense CNF 099 & 71 & 17 & & & 7 & & & & 3 & & \\
\hline Corynebacterium michiganense CNF 100 & 40 & 35 & & & 14 & & & & 5 & & \\
\hline “Corynebacterium aquaticum' CNF 038 & 29 & 54 & & 1 & 14 & 1 & & & 1 & & \\
\hline Corynebacterium insidiosum CNF 101 & 47 & 45 & & & 4 & & & & 1 & & \\
\hline Corynebacterium sp. strain CNF 133 & 59 & 24 & & 2 & 8 & & & & 1 & & \\
\hline Corynebacterium sp. strain CNF 134 & 38 & 33 & & 6 & 19 & & & & 1 & & \\
\hline \multicolumn{12}{|l|}{ Unclassified } \\
\hline Brevibacterium imperiale CNF 105 & 29 & 55 & & & 10 & & & & 3 & & \\
\hline
\end{tabular}

lar fatty acid methyl esters were prepared as follows. Cells were harvested by centrifugation, washed twice with distilled water, and lyophilized. Fatty acid methyl esters were liberated from $20 \mathrm{mg}$ of lyophilized cells by methanolysis at $100^{\circ} \mathrm{C}$ for $3 \mathrm{~h}$ with $2.5 \mathrm{ml}$ of $5 \%$ anhydrous methanolic $\mathrm{HCl}$ and were extracted three times with petroleum ether $(3 \mathrm{ml}$ each time).
Analytical methods. Fatty acid methyl esters were determined with a Shimadzu model GC-6A gas chromatograph and a Shimadzu model CR1-A chromatograph-data processor. Two kinds of glass columns were used to separate the fatty acid methyl esters. One column ( $5 \mathrm{~m}$ by $3 \mathrm{~mm}$ ) was packed with $10 \%$ diethyleneglycol succinate on Chromosorb W (type AW- 

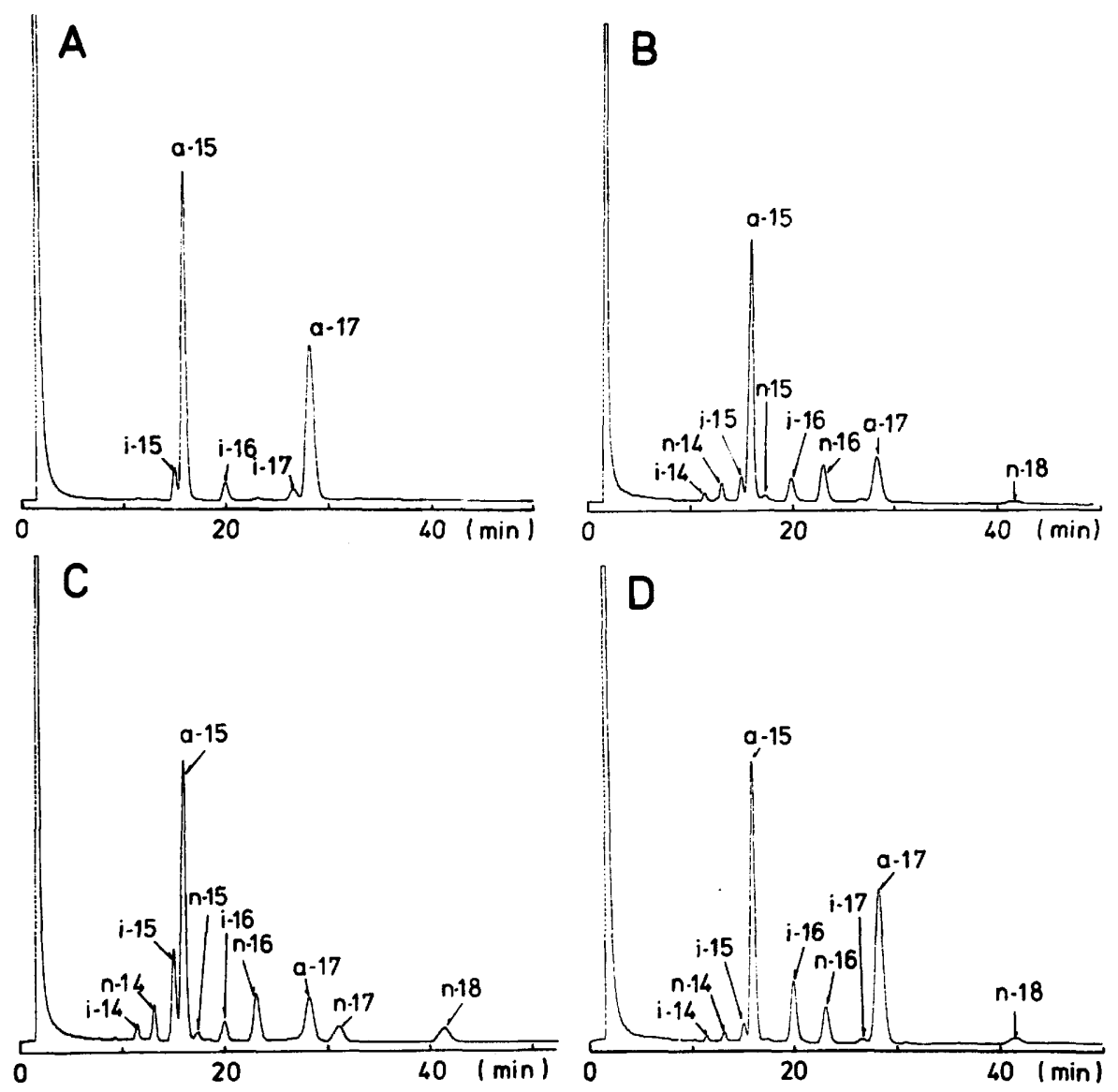

FIG. 2. Gas-liquid chromatograms of representatives of cellular fatty acid type II (iso-anteiso type). (A) Brevibacterium linens CNF 019 ${ }^{\mathrm{T}}$. (B) Arthrobacter globiformis CNF $022^{\mathrm{T}}$. (C) Cellulomonas fimi CNF $025^{\mathrm{T}}$. (D) Curtobacterium citreum CNF $026^{\mathrm{T}}$. A 5-m diethyleneglycol succinate column was used. For abbreviations of fatty acids, see text.

DMCS; 80 to 100 mesh), and the other column ( $2 \mathrm{~m}$ by $3 \mathrm{~mm}$ ) was packed with $5 \% \mathrm{OV}-1$ on Chromosorb $\mathrm{W}$ (type AW-DMCS; 80 to 100 mesh). Comparative analyses with the two types of columns were useful for fatty acid identification. Fatty acid methyl esters, L203, L-205, and BC MIX-L (obtained from Applied Sciences Laboratories, State College, Pa.) were used as standards.

Methyl esters of hydroxy fatty acids were separated from methyl esters of nonpolar acids by thin-layer chromatography on Kieselgel F-254 (E. Merck AG, Darmstadt, West Germany). The chromatograms were developed with a petroleum ether-diethyl ether (1:1, $\mathrm{vol} / \mathrm{vol}$ ) solvent system. Fractions were scraped from the chromatograms, stained with rhodamine $6 \mathrm{G}$, and compared with the reference hydroxy fatty acid fractions.

Gas-liquid chromatography-mass spectrometry was performed with a model GCMS-9000S spectrometer (Shimadzu-LKB) and a PAC 90 computer system, as described previously (43). Some fatty acid methyl esters were analyzed with a Hitachi model 163 gas chromatograph and a JEOL model JMS-D300 gas chromatograph-mass spectrometer. Both instruments were equipped with a capillary column $(50 \mathrm{~m}$ by 0.25 $\mathrm{mm}$ ) of Carbowax 20M.

Effects of culture conditions. The effects of culture conditions on cellular fatty acid composition were determined for some strains. Growth temperature (20, 27,30 , and $\left.37^{\circ} \mathrm{C}\right)$, culture age $(6,12,24,48$, and $120 \mathrm{~h})$, and growth media (medium $F$ and medium $G$ ) were varied independently. Medium $G$ contained $1 \%$ glucose, $0.5 \%$ Proteose Peptone (Difco), $0.5 \%$ sodium glutamate, $0.1 \% \mathrm{~K}_{2} \mathrm{HPO}_{4}, 0.02 \% \mathrm{MgSO}_{4} \cdot 7 \mathrm{H}_{2} \mathrm{O}$, and $0.01 \% \mathrm{KCl}$; the $\mathrm{pH}$ was adjusted to $7.2(49)$.

\section{RESULTS}

We identified four major groups of coryneform bacteria based on cellular fatty acid constituents. Each of these is described below.

Type I. Type I was characterized by the presence of saturated and monounsaturated straight-chain $\mathrm{C}_{16}$ and $\mathrm{C}_{18}$ fatty acids. In addition, some strains contained 10-methyl fatty 


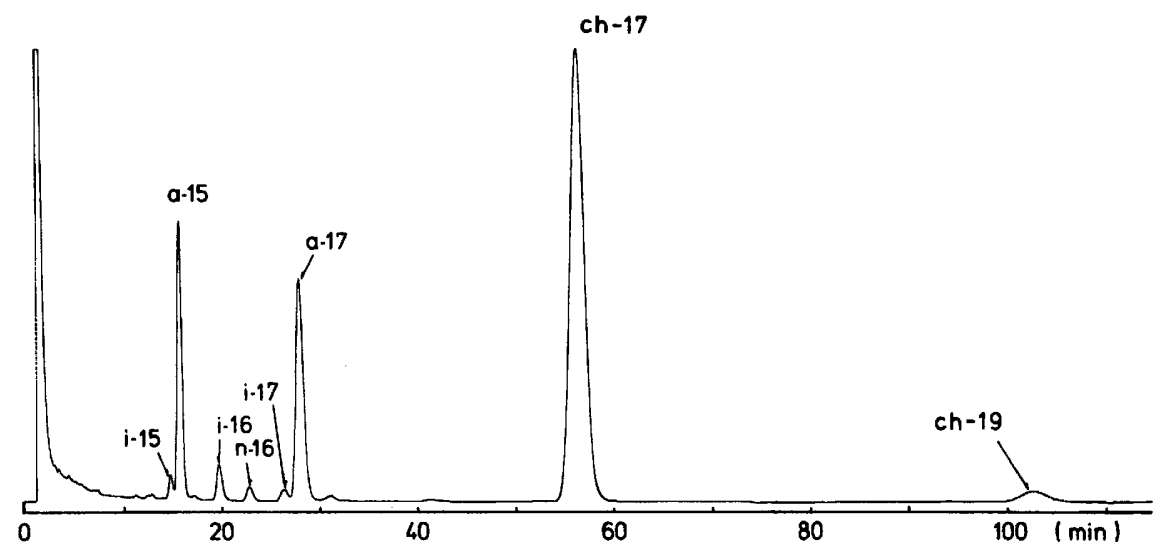

FIG. 3. Gas-liquid chromatogram of cellular fatty acids extracted from Curtobacterium pusillum $\mathrm{CNF} 106^{\mathrm{T}}$ (cellular fatty acid type III). A 5-m diethyleneglycol succinate column was used. For abbreviations of fatty acids, see text.

acids. Major components were $n$-hexadecanoic acid (n-16 acid), $n$-octadecenoic acid (18:1 acid), $n$-octadecanoic acid (n-18 acid), $n$-hexadecanoic acid (16:1 acid), and 10-methyl octadecanoic acid (10-Me-19 acid). The type I cellular fatty acid composition was found in all group 1 strains (49) and the strain of Caseobacter tested (Table 1). Type I strains were further divided into six subtypes (subtypes A through F) on the basis of the relative quantities of the acids that were found. Six representative gas-liquid chromatograms of these subtypes are shown in Fig. 1. The strains of subtype A contained exclusively $n-16$ and 18:1 acids. Nine strains, including Corynebacterium glutamicum CNF $016^{\mathrm{T}}$, were subtype A strains. Subtype B differed from subtype A by the occurrence of 10-Me-19 acid and included four strains. There was only one strain of subtype $C$, in which the fatty acids were mostly 16:1 and $\mathbf{n - 1 6}$ acids. The three subtype $\mathrm{D}$ strains had $18: 1, n-16$, and $n-18$ acids and differed from subtype $A$ strains by the presence of $n-18$ acid. In subtypes $E$ and $F$, odd-numbered straightchain acids, both saturated and unsaturated, were found, although the amounts were small. Subtype E strains contained moderate amounts of 10-methyl fatty acids, whereas none of these fatty acids were found in subtype $F$ strains.

Type II. Type II cellular fatty acid composi- tion included mainly anteiso and iso acids and was found in all tested strains belonging to group 2 (Brevibacterium), group 3 (Arthrobacter), and group 4 (Cellulomonas), 18 of 21 group 5 (Curtobacterium) strains tested, and all group 7 (coryneform bacteria with diaminobutyric acid in their cell walls) strains tested (Table 2). Gasliquid chromatograms of the fatty acids of four strains having type II fatty acid composition are shown in Fig. 2. The major components of this type were 12-methyl tetradecanoic acid (a-15 acid) and 14-methyl hexadecanoic acid (a-17 acid). The content of normal acids varied among strains. Normal acids in the two strains belonging to the genus Cellulomonas (group 4) accounted for approximately $25 \%$ of the total fatty acids detected, whereas two strains of Brevibacterium linens (group 2) possessed no normal acids. Brevibacterium imperiale CNF $105^{\mathrm{T}}$, which does not belong to any of the seven groups of Yamada and Komagata (49), also had type II fatty acid composition.

Type III. As previously reported (43), two strains of Curtobacterium pusillum possessed large amounts of $\omega$-cyclohexyl undecanoic acid (ch-17 acid), which is the characteristic fatty acid of type III (Table 3). A gas-liquid chromatogram of the cellular fatty acids of Curtobacterium pussilum $\mathrm{CNF} 106^{\mathrm{T}}$ is shown in Fig. 3.

TABLE 3. Cellular fatty acid compositions of coryneform bacteria: type III ( $\omega$-cyclohexyl type)

\begin{tabular}{|c|c|c|c|c|c|c|c|c|c|c|}
\hline \multirow{3}{*}{ Strain } & \multicolumn{10}{|c|}{ Fatty acid composition (\%) } \\
\hline & \multicolumn{2}{|c|}{ Cyclohexyl } & \multicolumn{2}{|c|}{ Anteiso } & \multicolumn{3}{|c|}{ Iso } & \multicolumn{3}{|c|}{ Normal } \\
\hline & ch-17 & ch-19 & $\overline{a-15}$ & $\overline{a-17}$ & $\mathrm{i}-15$ & $\mathrm{i}-16$ & $i-17$ & $n-15$ & $n-16$ & n-17 \\
\hline Curtobacterium pusillum CNF $106^{\mathrm{T}}$ & 64 & 3 & 12 & 17 & 1 & 2 & $\overline{1}$ & & 1 & \\
\hline Curtobacterium pusillum CNF 107 & 51 & 1 & 21 & 20 & 1 & 2 & & 1 & 1 & 1 \\
\hline Curtobacterium sp. strain CNF 165 & 5 & & 28 & 41 & 3 & 11 & 2 & & 7 & \\
\hline
\end{tabular}




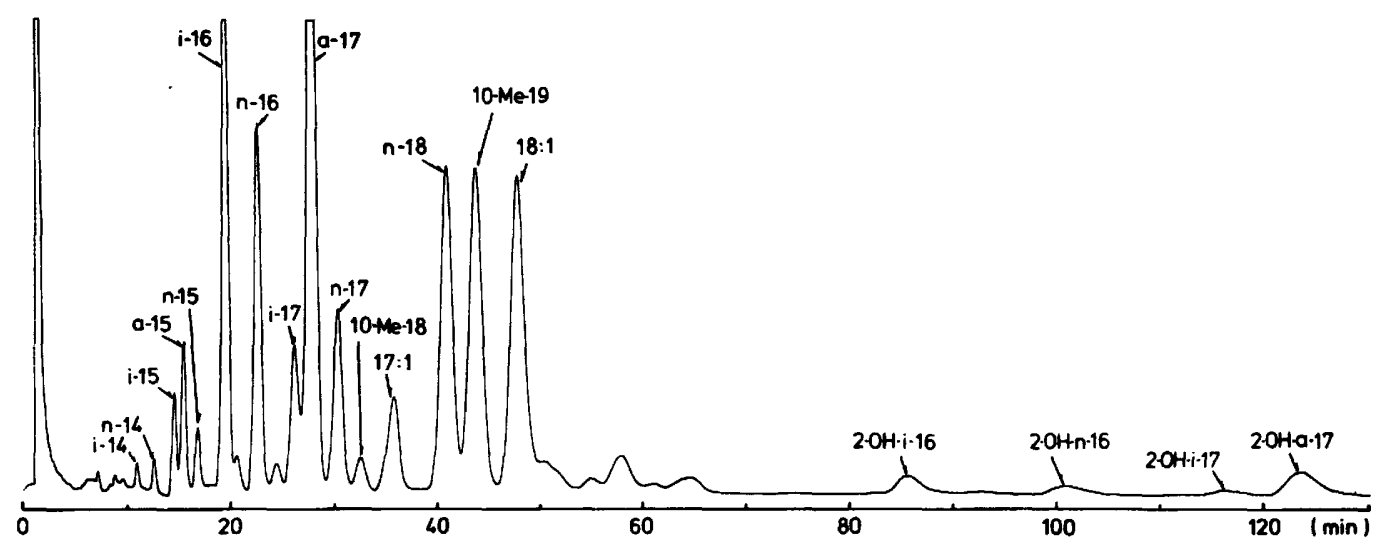

FIG. 4. Gas-liquid chromatogram of cellular fatty acids extracted from Arthrobacter simplex CNF $035^{T}$ (cellular fatty acid type IV). A 5-m diethyleneglycol succinate column was used. For abbreviations of fatty acids, see text.

Curtobacterium sp. strain CNF 165 also contained ch-17 acid, but it accounted for only 5\% of the total cellular fatty acids. $\omega$-Cyclohexyl fatty acids were not found in the other coryneform bacteria examined.

Type IV. The type IV fatty acid pattern was complex (Fig. 4). Many peaks corresponding to iso, anteiso, normal, saturated, unsaturated, 10methyl, and 2-hydroxy fatty acids were found in all group 6 strains tested. Group 6 strains are the strains with LL-diaminopimelic acid in their cell walls $(23,49)$. Table 4 shows the fatty acid compositions of the strains with type IV cellular fatty acids.

Effects of culture conditions. Selected strains with type I and II cellular fatty acid compositions were used for an analysis of cellular fatty acids under various growth conditions.

Representative strains of the six subtypes in type I were studied. In general, the composition of the culture medium did not affect the fatty acid composition. However, growth temperature did affect the cellular fatty acid composition. When cells were grown at higher temperatures, the content of saturated (normal and 10methyl) acids increased, and the content of unsaturated acids decreased (Fig. 5). The contents of 10-methyl fatty acids in the subtype B and $E$ strains tested increased as the cells aged. However, the content of 10 -methyl acids plus unsaturated acids was rather constant through $120 \mathrm{~h}$ of cultivation (Fig. 6).

Among the strains with type II fatty acid composition, nine representative strains were examined. The fatty acid compositions of these nine strains did not change through $120 \mathrm{~h}$ of cultivation, but there was a marked effect of culture medium composition. This effect differed among the strains (Fig. 7).

In four test strains the ratio of a-17 acid to a-15 acid increased as the growth temperature increased (Table 5).

\section{DISCUSSION}

The four types of cellular fatty acid composition in coryneform bacteria appear to be distinct and do not overlap, even when the culture conditions are changed slightly. Most of the strains studied belonged to type I (normal-unsaturated type) or type II (iso-anteiso type). These two types are quite different and are discussed separately below.

Type I fatty acid composition was found in all coryneform bacteria that have meso-diaminopimelic acid and arabinogalactan in their cell walls $(23,36)$. Some strains of Nocardia and related taxa that have the same cell wall components also possess type I subtype E cellular fatty acid composition (unpublished data). The apparent correlation between these two characters suggests that the cellular fatty acid composition of these organisms is taxonomically significant. Further study of this relationship among Rhodococcus strains will be required (30).

Type I subtype $A$, which is found in most glutamic acid-producing bacteria, uniformly consists of $n-16$ and $18: 1$ acids but not $n-18$ acid; on the other hand, $\mathrm{n}-18$ is found in subtype D.

Subtype C, which is found only in Corynebacterium diphtheriae CNF 017, contains small amounts of both saturated and unsaturated $\mathrm{C}_{18}$ fatty acids, as observed by Barksdale et al. (1). This pattern is considered to be characteristic for Corynebacterium diphtheriae. Further studies will be required to reveal the relationship of subtypes $A$ through $D$.

Among the six subtypes of type I, both subtype $B$ and subtype $E$ contain 10-methyl fatty acids. 10-Methyl fatty acids are formed by the 
TABLE 4. Cellular fatty acid compositions of coryneform bacteria: type IV (complex type)

\begin{tabular}{|c|c|c|c|c|c|c|c|c|c|c|c|c|c|c|}
\hline \multirow{3}{*}{ Strain } & \multicolumn{14}{|c|}{ Fatty acid composition (\%) } \\
\hline & \multicolumn{2}{|c|}{ Anteiso } & \multicolumn{8}{|c|}{ Iso } & \multicolumn{4}{|c|}{ Normal } \\
\hline & a-15 & $\mathrm{a}-17$ & $i-14$ & $\mathrm{i}-15$ & i-16 & $i-17$ & $\mathrm{i}-18$ & $i-19$ & $\mathrm{i}-16: 1$ & i-19:1 & n-14 & $n-15$ & n-16 & $n-17$ \\
\hline $\begin{array}{l}\text { Arthrobacter simplex CNF } 035^{\mathrm{T}} \\
\text { Arthrobacter simplex CNF } 091 \\
\text { Arthrobacter tumescens CNF } 067^{\mathrm{T}} \\
\text { "Brevibacterium lipolyticum" CNF } 036 \\
\text { "Brevibacterium lipid" CNF } 037\end{array}$ & $\begin{array}{r}2^{a} \\
1 \\
11 \\
1 \\
1\end{array}$ & $\begin{array}{r}18 \\
4 \\
7 \\
14 \\
13\end{array}$ & $\begin{array}{l}\mathbf{T} \\
1 \\
3\end{array}$ & $\begin{array}{r}1 \\
13 \\
39 \\
2 \\
2\end{array}$ & $\begin{array}{r}9 \\
18 \\
7 \\
12 \\
11\end{array}$ & $\begin{array}{r}3 \\
13 \\
2 \\
6 \\
8\end{array}$ & $\begin{array}{l}1 \\
1 \\
T \\
2 \\
1\end{array}$ & $\begin{array}{l}1 \\
1\end{array}$ & 4 & $\begin{array}{l}1 \\
1\end{array}$ & $\begin{array}{l}\mathbf{T} \\
\mathbf{T} \\
1\end{array}$ & $\begin{array}{l}1 \\
1 \\
1 \\
1 \\
\mathbf{T}\end{array}$ & $\begin{array}{l}7 \\
4 \\
2 \\
4 \\
5\end{array}$ & $\begin{array}{l}4 \\
7 \\
4 \\
3 \\
3\end{array}$ \\
\hline
\end{tabular}

${ }^{a}$ Values are percentages of the total fatty acids detected. T, Trace (less than $0.5 \%$ )

introduction of a methyl group from $S$-adenosylmethionine to the double bonds of the corresponding unsaturated acids $(19,27)$. In the present study, the content of 10-methyl acids increased with culture age, but the amount of 10methyl acids plus unsaturated acids was almost constant. Therefore, 10-methyl acids can be considered to be derivatives of the corresponding unsaturated acids. Because of this relationship, in quantitative comparisons of cellular fatty acid compositions the total contents of 10methyl acids and unsaturated acids should be considered together.

The difference between subtype $\mathrm{E}$ and subtype $F$ is solely the presence of 10-methyl acids. When the contents of 10-methyl acids are added to those of the corresponding unsaturated acids, subtype E shows a composition similar to that of subtype F. In fact, the strains of both subtypes fall into one cluster on the basis of DNA homology (42), and they are the only strains among the corynebacteria that possess the glycolyl type of cell wall $(44,45$; unpublished data). Therefore, strains of subtype $E$ and subtype $F$ are more closely related to each other than to other subtypes.

The contents of unsaturated acids decreased in proportion to increases in growth temperature (Fig. 6). This phenomenon has also been observed in Escherichia coli (19). Kawaguchi et al. (20) found the same thermal regulation in a cellfree system of fatty acid biosynthesis with Brevibacterium ammoniagenes CNF $096^{\mathrm{T}}$.

The distribution of type II cellular fatty acids was in agreement with the results obtained by other investigators, who also found that strains of Brevibacterium linens $(2,6)$, Arthrobacter (2), Cellulomonas (29), Curtobacterium (4), and coryneform bacteria with the diaminobutyric acid type of peptidoglycan (5) contain iso-anteiso cellular fatty acids. Although the major components are anteiso acids (a-15 and a-17 acids), some genera have additional distinctive differences in composition. Strains of Brevibacterium linens did not possess normal acids, whereas relatively large amounts of normal acids were found in the two strains of Cellulomonas. In strains of the genus Curtobacterium (group 5), i16 acid was always the third-most-abundant acid after the anteiso acids.

On the basis of cellular fatty acid composition, five strains of Curtobacterium testaceum, Arthrobacter terregens $\mathrm{CNF} 111^{\mathrm{T}}$, Curtobacterium saperdae CNF $058^{\mathrm{T}}$, and Curtobacterium $\mathrm{sp}$. strain CNF 116, which possess a glycolyl cell wall type $(44,45$; unpublished data), were not distinguished from other Curtobacterium strains which have an acetyl cell wall type.

Strains of both Brevibacterium linens and the genus Corynebacterium commonly have mesodiaminopimelic acid as the principal amino acid of the peptidoglycan. The chemotaxonomic differences between these two genera include the presence of arabinogalactan in the cell wall (23, 36) and the occurrence of mycolic acids (23). Strains of Brevibacterium linens can be clearly differentiated from corynebacteria (group 1) and a strain of Caseobacter by cellular fatty acid composition. The former have type II fatty acid composition, and the latter have type I.

The composition of iso-anteiso fatty acids in bacteria is ascribed to the primer specificity of the starting enzyme for fatty acid biosynthesis. Even-numbered iso acids, odd-numbered iso acids, and odd-numbered anteiso acids are synthesized from the primers valine, leucine, and isoleucine, respectively $(18,27)$. Therefore, differences in medium composition may be expected to change the cellular fatty acid composition, as shown in Fig. 7.

Table 5 shows that coryneform bacteria with type II fatty acid composition synthesize proportionately more longer fatty acids as the growth temperature increases. This phenomenon was observed in some thermophilic bacteria by Oshima and Miyagawa (33). It is evident that taxonomic comparisons of fatty acid composition should only be done with data obtained from cells grown under the same cultural conditions.

Type III cellular fatty acid composition is characterized by the occurrence of $\omega$-cyclohexyl fatty acids. These unusual fatty acids were found only in three Curtobacterium strains (Ta- 
TABLE 4-Continued

\begin{tabular}{|c|c|c|c|c|c|c|c|c|c|c|c|c|c|c|c|}
\hline \multicolumn{16}{|c|}{ Fatty acid composition (\%) } \\
\hline \multirow[b]{2}{*}{$\mathrm{n}-18$} & \multirow[b]{2}{*}{ n-19 } & \multirow[b]{2}{*}{$15: 1$} & \multirow[b]{2}{*}{$16: 1$} & \multirow[b]{2}{*}{ 17:1 } & \multirow[b]{2}{*}{$18: 1$} & \multirow[b]{2}{*}{ 19:1 } & \multicolumn{4}{|c|}{ 10-Methyl } & \multicolumn{5}{|c|}{ 2-Hydroxy } \\
\hline & & & & & & & 10-Me-17 & 10-Me-18 & 10-Me-19 & $10-\mathrm{Me}-20$ & h-a-17 & $h-i-16$ & h-a-17 & $h-n-16$ & h-n-17 \\
\hline $\begin{array}{r}11 \\
3 \\
1 \\
4 \\
9\end{array}$ & $\begin{array}{l}\mathrm{T} \\
\mathrm{T}\end{array}$ & 1 & $\begin{array}{l}1 \\
2 \\
3 \\
1 \\
1\end{array}$ & $\begin{array}{l}2 \\
5 \\
2 \\
5 \\
2\end{array}$ & $\begin{array}{r}13 \\
10 \\
4 \\
28 \\
15\end{array}$ & $\begin{array}{l}\mathbf{T} \\
\mathbf{T} \\
\mathbf{T} \\
1 \\
\mathbf{T}\end{array}$ & $\begin{array}{l}T \\
T\end{array}$ & $\begin{array}{l}1 \\
3 \\
5\end{array}$ & $\begin{array}{c}12 \\
6 \\
T \\
T \\
12\end{array}$ & $\begin{array}{l}\mathbf{T} \\
\mathbf{T}\end{array}$ & $\begin{array}{l}4 \\
\mathrm{~T}\end{array}$ & $\begin{array}{l}2 \\
1\end{array}$ & $\begin{array}{l}1 \\
1 \\
1 \\
2\end{array}$ & $\begin{array}{l}1 \\
\mathrm{~T} \\
\mathrm{~T} \\
1 \\
1\end{array}$ & $\mathbf{T}$ \\
\hline
\end{tabular}

ble 3). The presence of $\omega$-cyclohexyl fatty acids is considered to be a specific character of Curtobacterium pusillum. This species meets the concept of the genus Curtobacterium in phenotype and in chemotaxonomic profiles (49). Curtobacterium sp. strain CNF 165, which possesses a small amount of ch-17 acid, seems to be intermediate between type II and type III. When $\omega$ cyclohexyl fatty acids are excluded, the fatty acid components of these three Curtobacterium strains are essentially iso-anteiso acids, as for type II. These similarities indicate that type III is a variant of type II.

$\omega$-Cyclohexyl alkanes are found in crude oil, but until 1965 the possible origins of these compounds were unknown (28). Therefore, it is of interest that strains of Curtobacterium with $\omega$ cyclohexyl fatty acids have been isolated from oil brine in Japan (15).

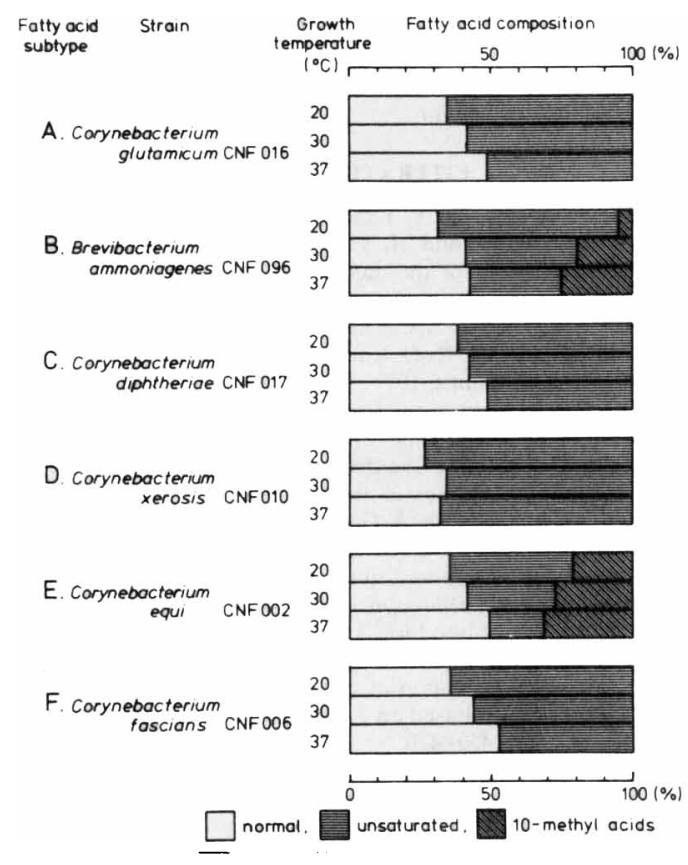

FIG. 5. Effect of growth temperature on the cellular fatty acid compositions of six type I coryneform bacterial strains (normal-unsaturated type).
Type IV (complex type) is found only in the coryneform bacteria with LL-diaminopimelic acid-containing peptidoglycan (group 6). The cellular fatty acid components of Arthrobacter simplex CNF $035^{\mathrm{T}}$ agreed well with the fatty acid components of phospholipids of the same strain studied by Yano et al. (51). Arthrobacter simplex CNF $035^{\mathrm{T}}$ and "Brevibacterium lipolyticum' CNF 036 and CNF 037 formed a single cluster based on DNA homology (42). Arthrobacter simplex CNF 035', "Brevibacterium lipolyticum' CNF 036, and Arthrobacter tumescens CNF 067 share the same menaquinone [MK-8( $\left.\left.\mathrm{H}_{4}\right)\right](3,50)$. These results support the homogeneity of group 6.

Our data indicate that when culture conditions are standardized, the cellular fatty acid profile becomes a reliable characteristic for taxonomic comparisons among coryneform bacteria. The

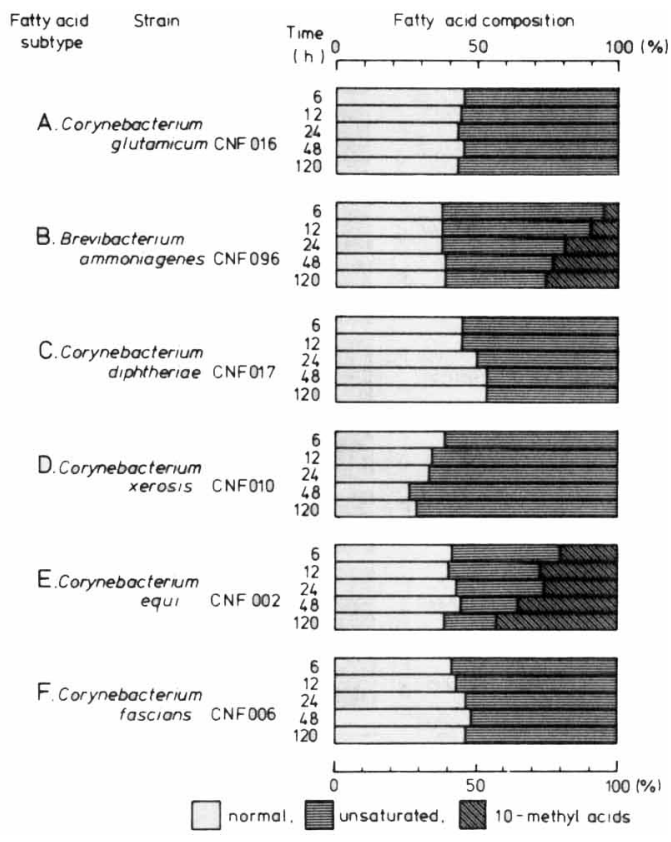

FIG. 6. Effect of culture age on the cellular fatty acid compositions of six type I coryneform bacterial strains (normal-unsaturated type). 
TABLE 5. Effect of growth temperature on the fatty acid compositions of type II coryneform bacteria (isoanteiso type)

\begin{tabular}{|c|c|c|c|c|c|c|c|c|c|c|}
\hline \multirow{3}{*}{ Strain } & \multirow{3}{*}{$\begin{array}{l}\text { Growth } \\
\text { temp }\left({ }^{\circ} \mathrm{C}\right)\end{array}$} & \multicolumn{8}{|c|}{ Fatty acid composition (\%) } & \multirow{3}{*}{$\begin{array}{c}\text { Ratio of } \\
\text { a-17 to } \\
\text { a-15 }\end{array}$} \\
\hline & & \multicolumn{2}{|c|}{ Anteiso } & \multicolumn{4}{|c|}{ Iso } & \multicolumn{2}{|c|}{ Normal } & \\
\hline & & a-15 & a-17 & $\mathrm{i}-14$ & $\mathrm{i}-15$ & $\mathrm{i}-16$ & $\mathrm{i}-17$ & n-14 & $n-16$ & \\
\hline Brevibacterium linens CNF $019^{\mathrm{T}}$ & $\begin{array}{l}20 \\
27 \\
37\end{array}$ & $\begin{array}{l}64 \\
56 \\
48\end{array}$ & $\begin{array}{l}27 \\
32 \\
40\end{array}$ & & $\begin{array}{l}4 \\
6 \\
3\end{array}$ & $\begin{array}{l}3 \\
4 \\
6\end{array}$ & $\begin{array}{l}2 \\
1\end{array}$ & & & $\begin{array}{l}0.43 \\
0.58 \\
0.83\end{array}$ \\
\hline "Brevibacterium helvolum" CNF 020 & $\begin{array}{l}20 \\
27 \\
37\end{array}$ & $\begin{array}{l}71 \\
61 \\
58\end{array}$ & $\begin{array}{r}9 \\
16 \\
15\end{array}$ & $\begin{array}{l}2 \\
1 \\
1\end{array}$ & $\begin{array}{r}9 \\
8 \\
15\end{array}$ & $\begin{array}{l}3 \\
7 \\
6\end{array}$ & $\begin{array}{l}1 \\
3\end{array}$ & $\begin{array}{l}2 \\
1\end{array}$ & $\begin{array}{l}3 \\
4 \\
2\end{array}$ & $\begin{array}{l}0.13 \\
0.26 \\
0.27\end{array}$ \\
\hline Arthrobacter ureafaciens CNF $023^{\mathrm{T}}$ & $\begin{array}{l}20 \\
27 \\
37\end{array}$ & $\begin{array}{l}78 \\
63 \\
59\end{array}$ & $\begin{array}{l}11 \\
19 \\
27\end{array}$ & $\begin{array}{l}1 \\
1 \\
1\end{array}$ & $\begin{array}{l}2 \\
5 \\
4\end{array}$ & $\begin{array}{r}5 \\
9 \\
7\end{array}$ & 1 & & $\begin{array}{l}3 \\
1 \\
2\end{array}$ & $\begin{array}{l}0.14 \\
0.30 \\
0.46\end{array}$ \\
\hline "Corynebacterium aquaticum" CNF 038 & $\begin{array}{l}20 \\
27 \\
37\end{array}$ & $\begin{array}{l}66 \\
33 \\
26\end{array}$ & $\begin{array}{l}15 \\
36 \\
50\end{array}$ & 1 & $\begin{array}{l}1 \\
5 \\
2\end{array}$ & $\begin{array}{l}10 \\
20 \\
18\end{array}$ & $\begin{array}{l}3 \\
2\end{array}$ & 2 & $\begin{array}{l}2 \\
1 \\
2\end{array}$ & $\begin{array}{l}0.23 \\
1.08 \\
1.93\end{array}$ \\
\hline
\end{tabular}

four major types of fatty acid composition correlate well with other chemotaxonomic data. Types I, II, and IV also agree completely with the dendrogram based on $16 \mathrm{~S}$ ribosomal ribonucleic acid cataloging of Stackebrandt et al. (41). Therefore, we believe that cellular fatty acid analysis will be extremely useful in overcoming many of the difficulties that have been encoun-

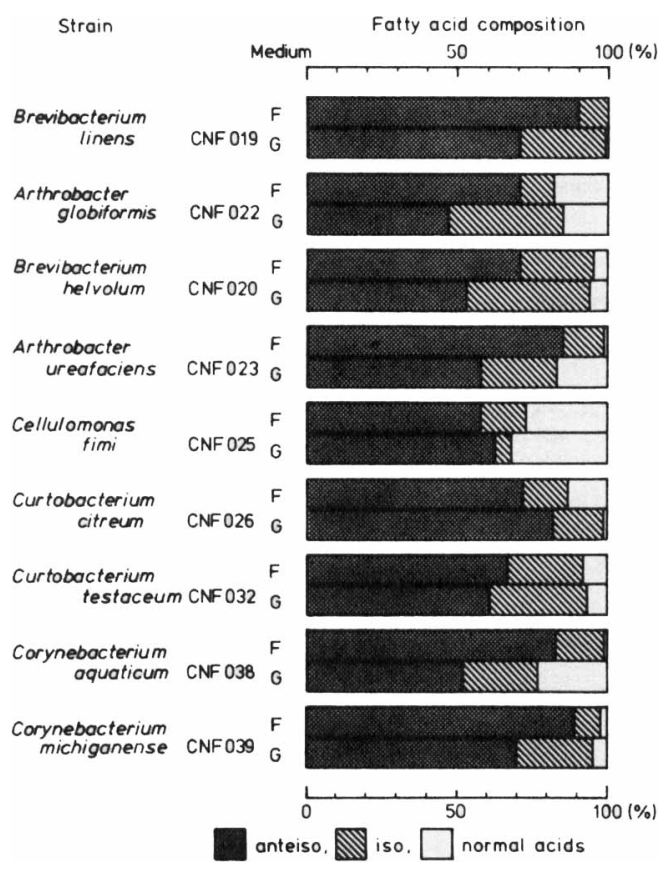

FIG. 7. Effect of culture medium on the cellular fatty acid compositions of nine type II coryneform bacterial strains (iso-anteiso type). For the compositions of media $F$ and $G$, see the text. tered in identifying and classifying the coryneform bacteria.

\section{ACKNOWLEDGMENTS}

We thank the following for kindly supplying cultures: $\mathbf{K}$. Yamada, Central Research Laboratories, Ajinomoto Co., Inc., Kawasaki, Japan; R. M. Keddie, University of Reading, Reading, England; Culture Collection Center, Institute of Applied Microbiology, University of Tokyo, Tokyo, Japan; Institute for Fermentation, Osaka, Japan; and National Collection of Industrial Bacteria, Aberdeen, Scotland. We are grateful to A. Kawaguchi and K. Uchida (Institute of Applied Microbiology, University of Tokyo) for their encouragement and valuable discussions and also to $\mathrm{S}$. Inoue (Tochigi $\mathrm{Re}$ search Laboratories, Kao Soap Co., Ltd., Tochigi, Japan) for analyses by gas-liquid chromatography-mass spectrometry using a capillary column.

\section{LITERATURE CITED}

1. Barksdale, L., M. A. Lanéelle, M. C. Pollice, J. Asselineau, M. Welby, and M. V. Norgard. 1979. Biological and chemical basis for the reclassification of Microbacterium flavum Orla-Jensen as Corynebacterium flavescens nom. nov. Int. J. Syst. Bacteriol. 29:222-233.

2. Bowie, I. S., M. R. Grigor, G. G. Dunckley, M. W. Loutit, and J. S. Loutit. 1972. The DNA base composition and fatty acid constitution of some gram-positive pleomorphic soil bacteria. Soil Biol. Biochem. 4:397-412.

3. Collins, M. D., M. Goodfellow, and D. E. Minnikin. 1979. Isoprenoid quinones in the classification of coryneform and related bacteria. J. Gen. Microbiol. 110:127-136.

4. Collins, M. D., M. Goodfellow, and D. E. Minnikin. 1980. Fatty acid, isoprenoid quinone and polar lipid composition in the classification of Curtobacterium and related taxa. J. Gen. Microbiol. 118:29-37.

5. Collins, M. D., and D. Jones. 1980 . Lipids in the classification and identification of coryneform bacteria containing peptidoglycans based on 2,4-diaminobutyric acid. J. Appl. Bacteriol. 48:459-470.

6. Collins, M. D., D. Jones, R. M. Keddie, and P. H. A. Sneath. 1980. Reclassification of Chromobacterium iodinum (Davis) in a redefined genus Brevibacterium (Breed) as Brevibacterium iodinum nom. rev., comb. nov. J. Gen. Microbiol. 120:1-10.

7. Collins, M. D., T. Piroux, M. Goodfellow, and D. E. Minnikin. 1977. Distribution of menaquinones in actino- 
mycetes and corynebacteria. J. Gen. Microbiol. 100:221230.

8. Crombach, W. H. J. 1972. DNA base composition of soil arthrobacters and other coryneforms from cheese and sea fish. Antonie van Leeuwenhoek J. Microbiol. Serol. 38:105-120.

9. Crombach, w. H. J. 1974. Relationships among coryneform bacteria from soil, cheese, and sea fish. Antonie van Leeuwenhoek J. Microbiol. Serol. 40:347-359.

10. Crombach, W. H. J. 1978. Caseobacter polymorphus gen. nov., sp. nov., a coryneform bacterium from cheese. Int. J. Syst. Bacteriol. 28:354-366.

11. De Rosa, M., A. Gambacorta, L. Minale, and J. D. Bu'lock. 1971. Cyclohexane fatty acids from a thermophilic bacterium. Chem. Commun. p. 1334.

12. Fiedler, F., and O. Kandler. 1973. Die Mureintypen in der Gattung Cellulomonas Bergey et al. Arch. Mirobiol. 89:41-50.

13. Fiedler, F., M. J. Schäffiler, and E. Stackebrandt. 1981. Biochemical and nucleic acid hybridisation studies on Brevibacterium linens and related strains. Arch. Microbiol. 129:85-93.

14. Hippehen, B., A. Röll, and K. Poralla. 1981. Occurrence in soil of thermo-acidophilic bacilli possessing $\omega$-cyclohexane fatty acids and hopanoids. Arch. Microbiol. 129:5355 .

15. lizuka, H., and K. Komagata. 1965. Microbiological studies on petroleum and natural gas. III. Determination of Brevibacterium, Arthrobacter, Micrococcus, Sarcina, Alcaligenes, and Achromobacter isolated from oil-brines in Japan. J. Gen. Appl. Microbiol. 11:1-14.

16. Ikemoto, S., K. Kato, and K. Komagata. 1978. Cellular fatty acid composition in methanol-utilizing bacteria. J. Gen. Appl. Microbiol. 24:41-49.

17. Ikemoto, S., H. Kuraishi, K. Komagata, R. Azuma, T. Suto, and H. Murooka. 1978. Cellular fatty acid composition in Pseudomonas species. J. Gen. Appl. Microbiol. 24:199-213.

18. Kaneda, T. 1977. Fatty acids of the genus Bacillus: an example of branched-chain preference. Bacteriol. Rev. 41:391-418.

19. Kates, M. 1964. Bacterial lipids. Adv. Lipid Res. 2:17-90.

20. Kawaguchi, A., Y. Seyama, K. Sasaki, S. Okuda, and T. Yamakawa. 1979. Thermal regulation of fatty acid synthetase from Brevibacterium ammoniagenes. J. Biochem. (Tokyo) 85:865-869.

21. Keddie, R. M. 1978. What do we mean by coryneform bacteria?, p. 1-12. In I. J. Bousfield and A. G. Callely (ed.), Coryneform bacteria. Academic Press, Inc., London.

22. Keddie, R. M., and I. J. Bousfield. 1980. Cell wall composition in the classification and identification of coryneform bacteria, p. 167-188. In M. Goodfellow and R. G. Board (ed.), Microbiological classification and identification. Academic Press, Inc., London.

23. Keddie, R. M., and G. L. Cure. 1977. The cell wall composition and distribution of free mycolic acids in named strains of coryneform bacteria and in isolates from various natural sources. J. Appl. Bacteriol. 42:229-252.

24. Komagata, K., and H. Iizuka. 1964. New species of Brevibacterium isolated from rice. Studies on the microorganisms of cereal grains, part VII. Nippon Nogeikagaku Kaishi 38:496-502.

25. Komura, I., K. Yamada, S. Otsuka, and K. Komagata. 1975. Taxonomic significance of phospholipids in coryneform and nocardioform bacteria. J. Gen. Appl. Microbiol. 21:251-261.

26. Lanélle, M. A., J. Asselineau, M. Welby, M. V. Norgard, T. Imaeda, M. C. Pollice, and L. Barksdale. 1980. Biological and chemical bases for the reclassification of Brevibacterium vitarumen (Bechdel et al.) Breed (Approved Lists, 1980 ) as Corynebacterium vitarumen (Bechdel et al.) comb. nov. and Brevibacterium liquefaciens Okabayashi and Masuo (Approved Lists, 1980) as Corynebacterium liquefaciens (Okabayashi and Masuo) comb. nov. Int. J. Syst. Bacteriol. 30:539-546.

27. Lennarz, W. J. 1966. Lipid metabolism in the bacteria. Adv. Lipid Res. 4:175-225.

28. Maxwell, J. R., C. T. Pillinger, and G. Eglington. 1971. Organic geochemistry. Q. Rev. Chem. Soc. 25:571-628.

29. Minnikin, D. E., M. D. Collins, and M. Goodfellow. 1979. Fatty acid and polar lipid composition in the classification of Cellulomonas, Oerskovia, and related taxa. J. Appl. Bacteriol. 47:87-95.

30. Minnikin, D. E., and M. Goodfellow. 1980 . Lipid composition in the classification and identification of acid-fast bacteria, p. 189-256. In M. Goodfellow and R. G. Board (ed.), Microbiological classification and identification. Academic Press, Inc., London.

31. Minnikin, D. E., M. Goodfellow, and M. D. Collins. 1978. Lipid composition in the classification and identification of coryneform and related taxa, p. 85-160. In I. J. Bousfield and A. G. Callely (ed.), Coryneform bacteria. Academic Press, Inc., London.

32. Oshima, M., and T. Ariga. 1975. $\omega$-Cyclohexyl fatty acids in acidophilic thermophilic bacteria. Studies on their presence, structure, and biosynthesis using precursors labeled with stable isotopes and radioisotopes. J. Biol. Chem. 250:6963-6968.

33. Oshima, M., and A. Miyagawa. 1974. Comparative studies on the fatty acid composition of moderately and extremely thermophilic bacteria. Lipids 9:476-480.

34. Oyaizu, H., and K. Komagata. 1981. Chemotaxonomic and phenotypic characterization of the strains of species in the Flavobacterium-Cytophaga complex. J. Gen. Appl. Microbiol. 27:57-107.

35. Rogosa, M., C. S. Cummins, R. A. Lelliot, and R. M. Keddie. 1974. Coryneform group of bacteria, p. 599-617. In R. E. Buchanan and N. E. Gibbons (ed.), Bergey's manual of determinative bacteriology, 8th ed. The Williams \& Wilkins Co., Baltimore.

36. Schleifer, R. H., and O. Kandler. 1972. Peptidoglycan types of bacterial cell walls and their taxonomic implications. Bacteriol. Rev. 36:407-477.

37. Skerman, V. B. D., V. McGowan, and P. H. A. Sneath (ed.). 1980. Approved lists of bacterial names. Int. J. Syst. Bacteriol. 30:225-420.

38. Skyring, G. W., and C. Quadling. 1970. Soil bacteria: a principal component analysis and guanine-cytosine contents of some arthrobacter-coryneform soil isolates and of some named cultures. Can. J. Microbiol. 16:95-106.

39. Stackebrandt, E., and F. Fiedler. 1979. DNA-DNA homology studies among strains of Arthrobacter and Brevibacterium. Arch. Microbiol. 120:289-295.

40. Stackebrandt, E., and O. Kandler. 1979. Taxonomy of the genus Cellulomonas, based on phenotypic characters and deoxyribonucleic acid-deoxyribonucleic acid homology, and proposal of seven neotype strains. Int. J. Syst. Bacteriol. 29:273-282.

41. Stackebrandt, E., B. J. Lewis, and C. R. Woese. 1980. The phylogenetic structure of the coryneform group of bacteria. Zentralbl. Bakteriol. Parasitenkd. Infectionskr. Hyg. Abt. 1 Orig. Reihe C 1:137-149.

42. Suzuki, K., T. Kaneko, and K. Komagata. 1981. Deoxyribonucleic acid homologies among coryneform bacteria. Int. J. Syst. Bacteriol. 31:131-138.

43. Suzuki, K., K. Saito, A. Kawaguchi, S. Okuda, and K. Komagata. 1981. Occurrence of $\omega$-cyclohexyl fatty acids in Curtobacterium pusillum strains. J. Gen. Appl. Microbiol. 27:261-266.

44. Uchida, K., and K. Aida. 1977. Acyl type of bacterial cell wall: its simple identification by colorimetric method. J. Gen. Appl. Microbiol. 23:249-260.

45. Uchida, K., and K. Aida. 1979. Taxonomic significance of cell-wall acyl type in Corynebacterium-MycobacteriumNocardia group by a glycolate test. J. Gen. Appl. Microbiol. 25:169-183.

46. Urakami, T., and K. Komagata. 1979. Cellular fatty acid composition and coenzyme $Q$ system in gram-negative 
methanol-utilizing bacteria. J. Gen. Appl. Microbiol. 25:343-360.

47. Yamada, K., and K. Komagata. 1970. Taxonomic studies on coryneform bacteria. II. Principal amino acids in the cell wall and their taxonomic significance. J. Gen. Appl. Microbiol. 16:103-113.

48. Yamada, K., and K. Komagata. 1970. Taxonomic studies on coryneform bacteria. III. DNA base composition of coryneform bacteria. J. Gen. Appl. Microbiol. 16:215224.
49. Yamada, K., and K. Komagata. 1972. Taxonomic studies on coryneform bacteria. V. Classification of coryneform bacteria. J. Gen. Appl. Microbiol. 18:417-431.

50. Yamada, Y., G. Inoue, Y. Tahara, and K. Kondo. 1976. The menaquinone system in the classification of coryneform and nocardioform bacteria and related organisms. J. Gen. Appl. Microbiol. 22:203-214.

51. Yano, I., Y. Furukawa, and M. Kusunose. 1970. 2-Hydroxy fatty acid-containing phospholipid of Arthrobacter simplex. Biochim. Biophys. Acta. 210:105-115. 